\title{
Different expression of TSH receptor and NIS genes in thyroid cancer: role of epigenetics
}

\section{Maria D’Agostino", Marialuisa Sponziello,", Cinzia Puppin ${ }^{3}$, Marilena Celano, Valentina Maggisano, Federica Baldan ${ }^{3}$, Marco Biffoni ${ }^{2}$, Stefania Bulotta, Cosimo Durante', Sebastiano Filetti', Giuseppe Damante ${ }^{3}$ and Diego Russo}

Department of Health Sciences, University of Catanzaro 'Magna Graecia', Campus 'S. Venuta', Viale Europa, Germaneto, 88100 Catanzaro, Italy Departments of 'Internal Medicine and Medical Specialties, and ' ${ }^{1}$ urgical Sciences, University of Roma 'Sapienza', 00161 Roma, Italy

${ }^{3}$ Department of Medical and Biological Sciences, University of Udine, 33100 Udine, Italy

*(M D'Agostino and M Sponziello contributed equally to this work)
Correspondence should be addressed to $D$ Russo

Email

d.russo@unicz.it

\begin{abstract}
The TSH receptor (TSHR) and sodium/iodide symporter (NIS) are key players in radioiodinebased treatment of differentiated thyroid cancers. While NIS (SLC5AS) expression is diminished/lost in most thyroid tumors, TSHR is usually preserved. To examine the mechanisms that regulate the expression of NIS and TSHR genes in thyroid tumor cells, we analyzed their expression after inhibition of ras-BRAF-MAPK and PI3K-Akt-mTOR pathways and the epigenetic control occurring at the gene promoter level in four human thyroid cancer cell lines. Quantitative real-time PCR was used to measure NIS and TSHR mRNA in thyroid cancer cell lines (TPC-1, BCPAP, WRO, and FTC-133). Western blotting was used to assess the levels of total and phosphorylated ERK and Akt. Chromatin immunoprecipitation was performed for investigating histone post-translational modifications of the TSHR and NIS genes. ERK and Akt inhibitors elicited different responses of the cells in terms of TSHR and NIS mRNA levels. Akt inhibition increased NIS transcript levels and reduced those of TSHR in FTC-133 cells but had no significant effects in BCPAP. ERK inhibition increased the expression of both genes in BCPAP cells but had no effects in FTC-133. Histone posttranslational modifications observed in the basal state of the four cell lines as well as in BCPAP treated with ERK inhibitor and FTC-133 treated with Akt inhibitor show cell- and gene-specific differences. In conclusion, our data indicate that in thyroid cancer cells the expression of TSHR and NIS genes is differently controlled by multiple mechanisms, including epigenetic events elicited by major signaling pathways involved in thyroid tumorigenesis.
\end{abstract}
Key Words
- NIS
- TSH receptor
- thyroid cancer
- MAPK
- Akt
- epigenetics

\author{
Journal of Molecular \\ Endocrinology \\ (2014) 52, 121-131
}

\section{Introduction}

Loss of differentiation is a common feature of thyroid cancers, and it has important prognostic implications. Radioactive iodine is the most effective method for managing recurrent and metastatic disease in these patients, but it requires adequate tumor tissue expression of genes that play key roles in iodine metabolism, in particular those encoding the thyroid-stimulating hormone receptor (TSHR) and the sodium/iodide 
symporter (NIS) (Schlumberger et al. 2007, Wartofsky \& Van Nostrand 2012). Many studies have demonstrated losses/reductions in NIS (SLC5AS) expression and function in primary and metastatic thyroid cancer cells as a result of oncogenic activation (Trapasso et al. 1999, Arturi et al. 2000, Puxeddu et al. 2008, Kogai \& Brent 2012). Alterations involving the ras-RAF-MAPK and PI3K-AktmTOR signal transduction pathways have been shown to play major roles in these changes (Xing 2010). Important contributions are also made by epigenetic events, such as changes in the methylation and acetylation of histones at the level of gene promoters (Russo et al. 2011, Galrão et al . 2013). For this reason, histone deacetylase inhibitors are being investigated as a potential means for restoring NIS expression and function in thyroid cancer cells (Puppin et al. 2005, Russo et al. 2013). As far as TSHR is concerned, early studies found that the expression of this gene in most thyroid cancers is similar to or slightly lower than that found in normal thyrocytes (Brabant et al. 1991, Ohta et al. 1991, Lazar et al. 1999, Sheils \& Sweenwy 1999, Tanaka et al. 2000, Gérard et al. 2003, Durante et al. 2007). Few data are available on the molecular mechanisms underlying the regulation of TSHR expression in thyroid cancer cells. Indeed, at variance with the reports in tumor tissues, loss of TSHR expression has been described in most of human thyroid cancer cells (Pilli et al. 2009; Sponziello M, Durante C, Russo D \& Filetti S, 2013, unpublished observations). However, hypermethylation of the TSHR promoter has been documented in a series of thyroid cancer tissues (Xing et al. 2003).

Different mechanisms thus seem to govern the expression of these fundamental markers of differentiation in thyroid cancers. Elucidation of these mechanisms might reveal important clues for the development of more effective therapeutic options for thyroid malignancies that are unresponsive to radioiodine. To this end, we examined the effects of specific MAPK and Akt pathway inhibitors on the expression of these two genes in thyroid cancer cell lines characterized by different basal levels of NIS/TSHR expression and the role played by post-translational histone modifications in the changes in NIS and TSHR expression in the cells treated with these inhibitors.

\section{Subjects and methods}

\section{Cell cultures}

We obtained human papillary thyroid carcinoma cells (TPC-1 and BCPAP) from Dr E Puxeddu of the University of Perugia. Follicular thyroid cancer cells were supplied by
Dr P E Goretzki of the Tumor Center Neuss-Düsseldorf (FTC-133 cells) and Dr A Fusco of the University of Naples (WRO cells). The thyroid origins of all cell lines were confirmed by genotype analysis (Schweppe et al. 2008). The cells cultured as described previously (Arturi et al. 2001), were treated with the MEK inhibitor U0126 $(10 \mu \mathrm{M}$ in DMSO) and Akt inhibitor IV (B2311; $0.5 \mu \mathrm{M}$ in DMSO) (both from Sigma-Aldrich; Hou et al. 2009). Control cells were exposed to DMSO alone at the same concentration used in U0126- and B2311-treated cultures.

\section{3-(4,5-Dimethylthiazol-2-yl)-2,5-diphenyltetrazolium bromide assays}

Cellular viability was evaluated with the 3-(4,5dimethylthiazol-2-yl)-2,5-diphenyltetrazolium bromide (MTT) method. Briefly, cells were seeded into 96-well plates (density, $3.5 \times 10^{3}$ cells/well for FTC-133 and $6 \times 10^{3}$ cells/well for BCPAP). The next day, the medium was replaced with a fresh medium, DMSO alone (controls) or containing U0126 $(10 \mu \mathrm{M})$ or B2311 $(0.5 \mu \mathrm{M})$. After 24 and $48 \mathrm{~h}$ of incubation, the medium was replaced with phenol red-free medium containing MTT $(0.5 \mathrm{mg} / \mathrm{ml}$; Sigma-Aldrich). Four hours later, the solubilized formazan product was quantified with a microplate spectrophotometer (xMark Spectrophotometer Microplate, Bio-Rad) at a wavelength of $540-690 \mathrm{~nm}$.

\section{RNA extraction and real-time PCR}

The TRIzol method (Invitrogen) was used to extract total RNA from thyroid cancer cells (untreated or treated with U0126 or B2311). TSHR and NIS levels were determined with real-time quantitative RT-PCR, as described previously (D'Agostino et al. 2012, Celano et al. 2013). The same reaction was performed for the evaluation of the transcript levels of thyroglobulin $(T g)$, thyroperoxidase (TPO), PAX8, NKX2.1, and FOXE1 genes. Two micrograms of RNA were reverse transcribed in a $20 \mu$ reaction volume using the High Capacity cDNA Kit (Applied Biosystems). The cDNAs were then diluted 1:5 in nuclease-free $\mathrm{H}_{2} \mathrm{O}$ (Gibco) and then amplified in an Applied Biosystems 7900HT fast real-time PCR Sequence Detection System (Applied Biosystems) using fast quantitative PCR thermal cycler parameters. A $20 \mu \mathrm{l}$ reaction contained $1 \mu \mathrm{l}$ of cDNA, $10 \mu \mathrm{l}$ TaqMan Fast Universal PCR Master Mix (Applied Biosystems), and $1 \mu \mathrm{l}$ of a primer/probe mixture for each gene evaluated. The $\beta$-actin gene was used as an endogenous reference. All amplification reactions were performed in triplicate, and the threshold cycles

Published by Bioscientifica Ltd. 
(identified with Applied Biosystems Software, SDS version 2.2.1) of the three reactions were averaged. Results were obtained by the $2^{-\Delta \Delta C t}$ method (Livak \& Schmittgen 2001) and normalized to a sample of control (untreated) cells.

\section{Protein extraction and western blotting}

Total proteins were extracted from the cells treated with U0126 or B2311, as described previously (D'Agostino et al. 2012). The cell lysates were quantified spectrophotometrically using the Bradford method. The samples $(20 \mu \mathrm{g})$ were loaded onto a $12 \%$ SDS-polyacrylamide gel and subjected to electrophoresis at a constant voltage $(120 \mathrm{~V})$. The resolved proteins were transferred to Hybond-P ECL nitrocellulose membranes (GE Healthcare, Milan, Italy) and blocked for $1 \mathrm{~h}$ at room temperature with TTBS/milk (TBS, $1 \%$ Tween $20,5 \%$ nonfat dry milk). The membranes were then incubated overnight at $4{ }^{\circ} \mathrm{C}$ with the following primary antibodies (in TTBS/milk): polyclonal anti-Akt (1:1000) and anti-phospho-Akt antibodies (1:500), both from Cell Signaling Technology (Danvers, MA, USA); polyclonal anti-ERK1,2 (1:2000) and monoclonal anti-phospho-ERK1,2 (1:1000) antibodies (Santa Cruz Biotech.). After one 15-min and two 5-min washes in TTBS, the membranes were incubated with HRP-conjugated secondary antibodies (Transduction Laboratories, Lexington, TX, USA; 1:10 000) in TTBS/milk, and the proteins were visualized with ECL Prime Reagent (GE Healthcare).

Global histone modifications were analyzed after histone acidic extraction. Briefly, the cell pellet was suspended in $\mathrm{HCl} 0.5 \mathrm{M}$ added with phenylmethylsulphonyl fluoride and a Protease Inhibitor Cocktail (Sigma-Aldrich). Then the lysate was sonicated for $10 \mathrm{~s}$ three times and centrifuged at $2500 \mathrm{~g}, 10 \mathrm{~min}, 4^{\circ} \mathrm{C}$. The supernatant was collected and processed twice as described earlier. The total supernatant of the three extractions was precipitated with ten volumes of cold acetone, at $-20^{\circ} \mathrm{C}$ overnight. The sample was then centrifuged at $2500 \mathrm{~g}, 15 \mathrm{~min}, 4^{\circ} \mathrm{C}$; the supernatant was discarded and the pellet was resuspended in water. For western blot analysis, $15 \mu \mathrm{g}$ protein extracts were electrophoresed on $18 \%$ SDS-PAGE. Proteins were then transferred to nitrocellulose membranes and were saturated by incubating for $1 \mathrm{~h}$ with $5 \%$ nonfat dry milk in PBS/0.1\% Tween 20. The membranes were then incubated overnight with rabbit polyclonal anti-acetyl-histone $\mathrm{H} 3$ antibody (Millipore Corporation, Billerica, MA, USA), histone H3 trimethyl Lys4 antibody (Active Motif, Carlsbad, CA, USA), histone H3 trimethyl Lys27 antibody
(Active Motif), or rabbit polyclonal anti $\mathrm{H} 3$ antibody (BioVision, Inc. Headquarters, Milpitas, CA, USA). After three washes with PBS $0.1 \%$ Tween 20 , the membranes were incubated with anti-rabbit immunoglobulin coupled with peroxidase (Sigma-Aldrich). After $2 \mathrm{~h}$ of incubation, the membranes were washed three times with PBS 0.1\% Tween 20, and the blots were developed using Chemidoc XRS (Bio-Rad) with the chemiluminescence procedure (GE Healthcare).

\section{Chromatin immunoprecipitation}

Cross-linkage of control and test substance-treated TPC-1, WRO, BCPAP, and FTC-133 cells was produced by exposure to formaldehyde (final concentration, 1\%) at $37^{\circ} \mathrm{C}$ for $10 \mathrm{~min}$ before harvesting. The cells were then washed twice with ice-cold PBS, scraped into $1 \mathrm{ml}$ of ice-cold PBS supplemented with protease inhibitors, and centrifuged for $5 \mathrm{~min}$ at $3500 \mathrm{~g}\left(4^{\circ} \mathrm{C}\right)$. The cell pellets were suspended in the cell lysis buffer (1\% SDS, $10 \mathrm{mM}$ EDTA, $50 \mathrm{mM}$ Tris- $\mathrm{HCl}, \mathrm{pH} 8.1$, and protease inhibitors) and incubated on ice for $10 \mathrm{~min}$. The lysed samples were sonicated to generate chromatin fragments with an average length of $\sim 200-600 \mathrm{bp}$. After centrifugation at $11000 \mathrm{~g}$ for $10 \mathrm{~min}$ at $4{ }^{\circ} \mathrm{C}$, the supernatants were collected, and the samples were diluted tenfold with dilution buffer $(0.01 \%$ SDS, $1.1 \%$ Triton X-100, $1.2 \mathrm{mM}$ EDTA, $16.7 \mathrm{mM}$ Tris-HCl, pH 8.1, and $167 \mathrm{mM} \mathrm{NaCl}$ ). An aliquot (10\%) saved as 'total input chromatin' was processed with the eluted immunoprecipitates, beginning with the cross-link reversal step. The samples were incubated $\left(30 \mathrm{~min}, 4{ }^{\circ} \mathrm{C}\right.$, on a rotating platform) for preclearing with $80 \mu \mathrm{l}$ of salmon sperm DNA/protein-Aagarose beads. The beads were then centrifuged (1 min at $3500 \mathrm{~g}$ ), and the supernatant fractions were collected and immunoprecipitated overnight at $4{ }^{\circ} \mathrm{C}$ with $10 \mu \mathrm{g}$ of antiH3 acetylated polyclonal rabbit antibody (cat no. 06-599, Upstate, Millipore Corporation, Lake Placid, NY, USA); H3K4 trimethyl polyclonal rabbit antibody (cat no. 39159, Active Motif); or H3K27 trimethyl polyclonal rabbit antibody (cat no. 39155, Active Motif). All of these antibodies are appropriate for chromatin immunoprecipitation (ChIP) assays, as demonstrated in previous studies (Braunstein et al. 1996, Ieda et al. 2010, Lavarone et al. 2013). The samples and negative controls were incubated with $60 \mu \mathrm{l}$ of salmon sperm DNA/protein-A-agarose beads for $1 \mathrm{~h}$ at $4{ }^{\circ} \mathrm{C}$. The beads were pelleted by centrifugation and washed for $5 \mathrm{~min}$ on a rotating platform with $1 \mathrm{ml}$ of each of the following buffers: low salt $(0.1 \%$ SDS, $1 \%$ Triton X-100, 2 mM EDTA, 20 mM Tris-HCl, pH 8.1, and

Published by Bioscientifica Ltd. 
Table 1 Primers used for readout of ChIP assays

\begin{tabular}{|c|c|c|c|}
\hline & Primer forward & Primer reverse & Probe \\
\hline NIS & $\begin{array}{c}\text { TGCCCTCTCTG- } \\
\text { AGCCTCAAT }\end{array}$ & $\begin{array}{l}\text { CCTGATCACAGCTGT- } \\
\text { CACTGTCT }\end{array}$ & $\begin{array}{l}\text { TCCCCACCTGT- } \\
\text { CAAC }\end{array}$ \\
\hline TSHR & $\begin{array}{l}\text { CCACAGTGGT- } \\
\text { GAGGTCACA }\end{array}$ & $\begin{array}{l}\text { GTTACCCCAGGC- } \\
\text { CAAAGGA }\end{array}$ & $\begin{array}{l}\text { CCTTGGAGCC- } \\
\text { СТCCCTC }\end{array}$ \\
\hline
\end{tabular}

$150 \mathrm{mM} \mathrm{NaCl})$; high salt (0.1\% SDS, 1\% Triton X-100, 2 mM EDTA, 20 mM Tris- $\mathrm{HCl}, \mathrm{pH}$ 8.1, and $500 \mathrm{mM} \mathrm{NaCl}$;; $\mathrm{LiCl}$ wash buffer (0.25 M LiCl, 1\% NP40, 1\% deoxycholate, $1 \mathrm{mM}$ EDTA, $10 \mathrm{mM}$ Tris-HCl, and $\mathrm{pH} 8.1$ ); and TE buffer (10 mM Tris-HCl, $1 \mathrm{mM}$ EDTA, and $\mathrm{pH}$ 8.0). After each wash, samples were centrifuged at $4{ }^{\circ} \mathrm{C}$ for $1 \mathrm{~min}$ at $500 \mathrm{~g}$ and the supernatant was discarded. Immunocomplexes were eluted from beads with elution buffer (1\% SDS and $0.1 \mathrm{M} \mathrm{NaHCO} 3$ ), and cross-linkage was reversed by incubation at $65^{\circ} \mathrm{C}$ for $4 \mathrm{~h}$. After the addition of proteinase $\mathrm{K}$, Tris- $\mathrm{HCl} \mathrm{pH} 6.5$, and EDTA $0.5 \mathrm{M}$, the samples were incubated for $1 \mathrm{~h}$ at $45^{\circ} \mathrm{C}$. DNA was purified with phenol/chloroform extraction followed by ethanol precipitation and used as a template in quantitative absolute PCR with the reaction primers listed in Table 1. After PCRs, acetylated or methylated H3 levels were measured and expressed as ratios of signals recorded after and before (input) immunoprecipitation.

\section{Statistical analysis}

TSHR and NIS mRNA levels were expressed as means \pm s.D., and differences were analyzed with the Tukey-Kramer multiple comparisons test performed with GrafPAD Software for Science (San Diego, CA, USA). FOXE1, NKX2.1, $T g$, and PAX8 mRNA levels were expressed as means \pm s.D., and the significance of differences was assessed with the $t$-test. $P$ values $<0.05$ were regarded as statistically significant. Data analysis was performed by using StatView 5.0.1 Software (SAS Institute, Inc., Cary, NC, USA).

\section{Results}

\section{TSHR and NIS gene expression and regulation in thyroid cancer cell lines}

Our first goal was to identify the regulatory mechanisms responsible for the NIS and TSHR mRNA expression patterns described in thyroid tumors. In vitro experiments were conducted in four human thyroid cancer cell lines characterized by different NIS and TSHR expression profiles. As shown in Fig. 1A, TSHR mRNA was detectable (i.e. present after fewer than 38 cycles of amplification) in BCPAP cells but not in TPC- 1 cells (both of which are PTC-derived). The highest levels (appearance after 30 cycles of amplification) were observed in FTC-133 cells, and no TSHR transcript was detected in the second follicular cell line, WRO. In contrast, NIS mRNA was detected only in WRO and BCPAP cells (threshold cycles: 36.0 and 36.7 for WRO and BCPAP respectively, 37.8 for FTC-133 cells; Fig. 1A).

To determine whether these patterns reflect cellline-specific forms of epigenetic control of gene expression, we performed ChIP experiments using primers specific for the minimal promoter sequences of TSHR and NIS (Fig. 1B). We evaluated the presence of histone H3 marks associated with active transcription (i.e. acetylation of lysines 9 and 14 (H3K9K14ac), trimethylation of lysine 4 (H3K4me3); Barsky et al. 1997, Santos-Rosa et al. 2002, Pokholok et al. 2005, Rando 2007) or with transcriptional repression (i.e. trimethylation of lysine 27 (H3K27me3); Barsky et al. 1997, Füllgrabe et al. 2011). In experiments focusing on the TSHR promoter, FTC-133 cells displayed the highest levels of H3K9K14ac and H3K4me3 (transcription-permissive) and the lowest levels of H3K27me3 (transcription-repressive), whereas BCPAP, TPC-1, and WRO cells all had very high levels of H3K27me3 (Fig. 1B). As for the NIS gene promoter, the post-translational $\mathrm{H} 3$ modifications we analyzed showed no correlation with NIS mRNA levels observed in the cell lines. Indeed, H3K27me3 levels were highest in WRO cells, which had exhibited the highest levels of NIS mRNA (Fig. 1B).

These data clearly indicate that TSHR and NIS transcript levels in FTC-133 cells are subjected to different forms of epigenetic control. In the context of current models of epigenetic regulation of gene expression (Barsky et al. 1997, Santos-Rosa et al. 2002, Pokholok et al. 2005, Rando 2007, Füllgrabe et al. 2011), the post-translational H3 modifications in the TSHR promoter region are fully consistent with the TSHR mRNA levels observed in the same cell lines, but this is not true for the NIS gene (Barsky et al. 1997, Santos-Rosa et al. 2002, Pokholok et al. 2005, Rando 2007, Füllgrabe et al. 2011).

\section{Modulation of two major signal transduction pathways involved in thyroid tumorigenesis}

In the next set of experiments, we exposed FTC-133 and BCPAP cells (the two lines with detectable levels of TSHR mRNA) to the MEK inhibitor U0126 $(10 \mu \mathrm{M})$ and the

Published by Bioscientifica Ltd. 
A
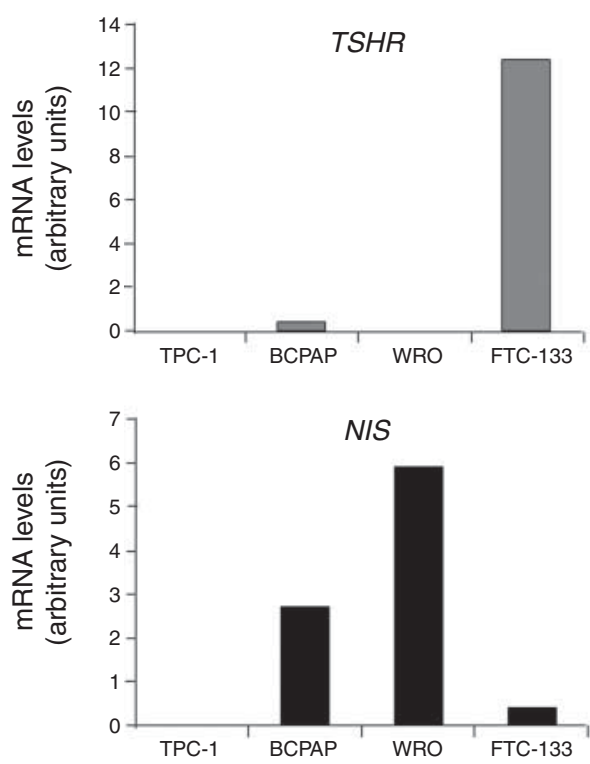

B

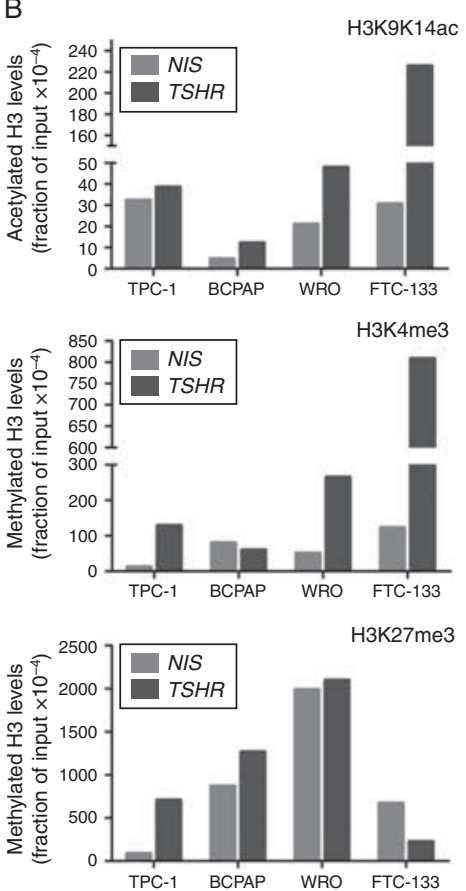

\section{Figure 1}

Expression levels and histone post-translational modifications of TSHR and NIS genes in TPC-1, BCPAP, WRO, and FTC-133 cells. (A) mRNA levels. RNA extraction and real time PCR are described in 'Subjects and methods' section. For each cell line the results were normalized against $\beta$-actin and expressed in arbitrary unit $\left(2^{-\Delta C t}\right)$. (B) Histone $\mathrm{H} 3$ post-translational

Akt inhibitor B2311 $(0.5 \mu \mathrm{M})$. Both have been shown to induce NIS expression and function in other models of thyroid and non-thyroid cancer cells (Kogai et al. 2008, Hou et al. 2010, Liu et al. 2012).

As shown in Fig. 2A, western blotting showed that, at the doses used, U0126 and B2311 clearly reduced the phosphorylation of ERK or Akt respectively in both cell lines. However, the effects of inhibitors on NIS and TSHR mRNA levels were both gene- and cell line-specific (Fig. 2B). After $30 \mathrm{~h}$ of exposure to B2311, FTC-133 cells exhibited upregulated NIS transcription ( 2.5-fold increases over control levels, $P<0.01)$ and downregulated expression of TSHR (approximately fivefold reductions compared with controls, $P<0.01$ ), but no significant changes in the expression of either gene were detected in BCPAP cells. In contrast, MEK inhibition with U0126 significantly increased the expression of both NIS and TSHR in BCPAP cells but had no effects in FTC-133 cells (Fig. 2B). In addition to NIS and TSHR, effects of U0126 and B2311 on the expression of PAX8, NKX2.1, FOXE1, Tg, and TPO genes were evaluated in FTC-133 and BCPAP cells. Both in the basal and in stimulated states TPO was never modifications. Bars indicate levels of acetylation at lysines 9 and 14 (top)، trimethylation at lysine 4 (middle), and trimethylation at lysine 27 (bottom). Each bar represents the mean value of three different determinations. For each bar S.D. is not above $15 \%$ of each value.

detectable in all these cell lines. As shown in Fig. 3, the general profile of thyroid-specific gene expression after ERK and Akt inhibition appears to be gene- and cell line-specific.

To determine whether post-translational modifications of histone $\mathrm{H} 3$ were involved in the changes in TSHR and NIS expression induced by the two inhibitors, we performed ChIP assays on BCPAP cells treated for $24 \mathrm{~h}$ with U0126 and on FTC-133 cells exposed for $24 \mathrm{~h}$ to B2311. The results are shown in Fig. 4A. In FTC-133 cells, B2311-mediated AKT inhibition reduced H3K9K14ac and H3K4me3 levels (transcription activation marks) and increased levels of H3K27me3 (transcription repression) at the level of the TSHR promoter, findings that were consistent with the TSHR transcript levels shown in Fig. 2B. In contrast, at the NIS gene, instead, the same treatment decreased H3K9K14ac and H3K4me3 levels and increased levels of H3K27me3. In BCPAP cells, where MEK inhibition had increased NIS and TSHR mRNA levels (Fig. 2B), U0126 increased transcriptional activation marks (H3K9K14ac and H3K4me3) at the TSHR promoter, but had no effect on that of the NIS gene (Fig. 4A).

Published by Bioscientifica Ltd. 
A

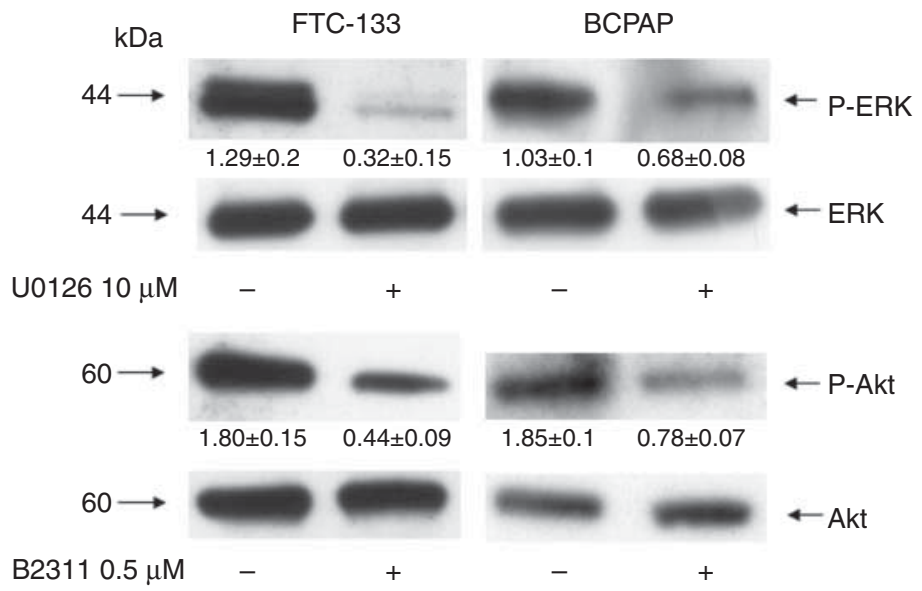

B

FTC-133
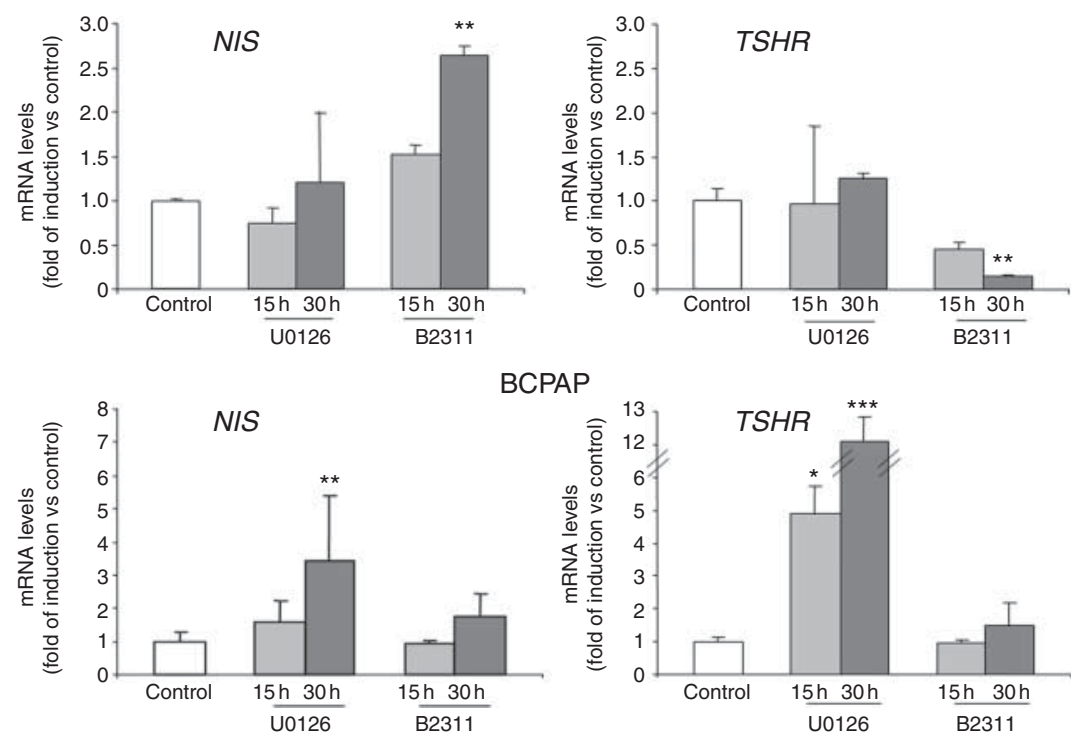

Figure 2

Effects of MEK and Akt inhibitors in FTC-133 and BCPAP cells. (A) Effects on ERK and Akt phosphorylation. Western blot analysis of phospho-ERK and phospho-Akt expression in FTC-133 and BCPAP cell lines treated with MEK inhibitor U0126 at $10 \mu \mathrm{M}$ and the Akt inhibitor IV (B2311) at $0.5 \mu \mathrm{M}$. Total ERK and Akt were used as internal controls. Numbers reported in figure indicate mean values \pm s.D. of $p$-ERK and $p$-Akt of three different experiments. Each value was normalized with respect to total ERK and Akt levels. An immunoblot representative of three experiments is shown.

In order to test whether the effects induced by B2311 and UO126 on histone post-translational modifications are specific for NIS or TSHR genes, the effects on global histone levels were investigated by western blot. As shown in Fig. 4B, histone recovery was lower in FTC-133 than in BCPAP. Nevertheless, it is clear that the only significant effect that we were able to detect was the inhibitory effect of U0126 in BCPAP on H3K4me3 levels. These data indicate that most effects induced by B2311 on FTC-133

(B) Effects on TSHR and NIS expression in FTC-133 and BCPAP cell lines after treatment with MEK inhibitor U0126 at $10 \mu \mathrm{M}$ and Akt inhibitor IV (B2311) at $0.5 \mu \mathrm{M}$ for 15 and $30 \mathrm{~h}$. Total RNA was extracted as described in 'Subjects and methods' section. Results are expressed as the mean \pm s.D. of values obtained from at least three different experiments and for endogenous control $\beta$-actin is used. Statistical analysis was performed using the Tukey-Kramer multiple comparisons test. ${ }^{*} P<0.05, * * P<0.01$, and $* * * P<0.001$

and U0126 on BCPAP at the level of histone posttranslational modifications of NIS and TSHR promoter are gene-specific and not related to global effects.

These data clearly demonstrate that in thyroid cancer cell lines post-translational histone $\mathrm{H} 3$ modifications at TSHR and NIS are regulated by MEK and Akt signaling pathways. The effects of this regulation on the TSHR gene are fully consistent with current models of epigenetic modulation of transcription. However, this is not true for 

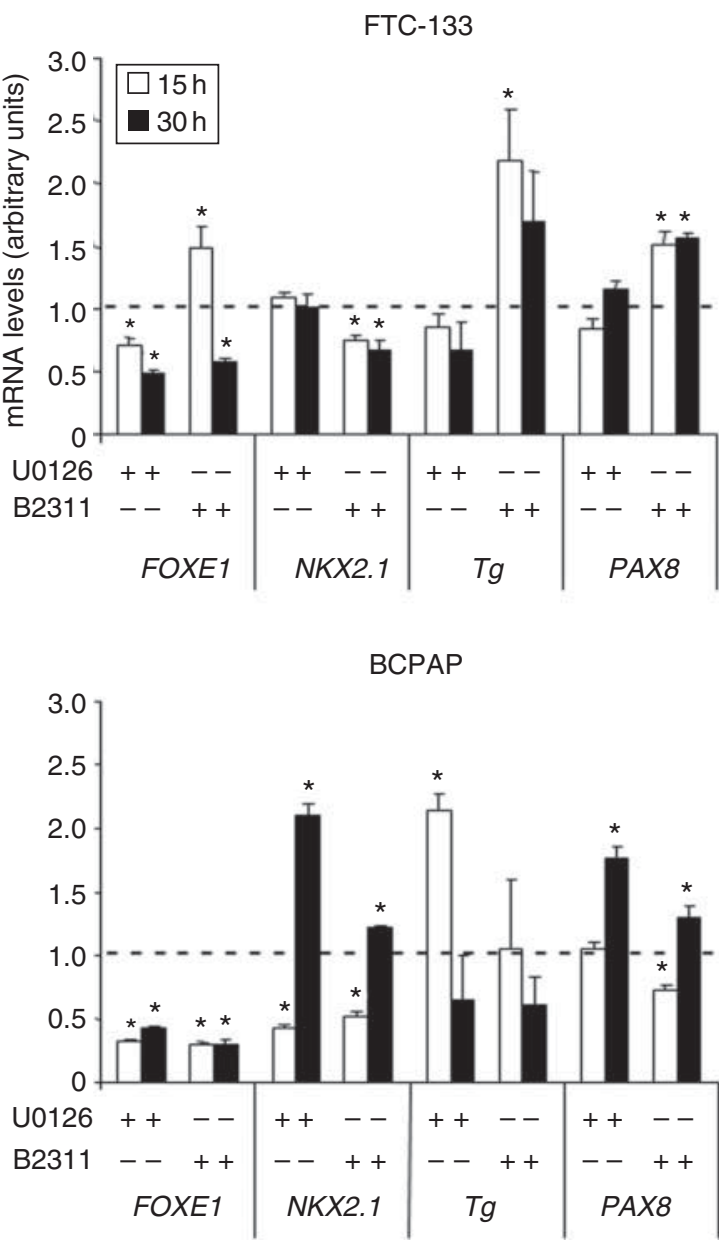

Figure 3

Effects of MEK and Akt inhibitors on other thyroid-specific gene expression. Expression of FOXE, NKX2.1, PAX8, and Tg expression in FTC-133 and BCPAP cell lines after treatment with MEK inhibitor U0126 at $10 \mu \mathrm{M}$ and Akt inhibitor IV (B2311) at $0.5 \mu \mathrm{M}$ for 15 and $30 \mathrm{~h}$. Total RNA was extracted as described in 'Subjects and methods' section. Results are expressed as fold of increase/decrease with respect to untreated cells, considered arbitrarily as 1 (horizontal dashed line). Each column indicates the mean \pm s.D. value obtained from at least three different experiments. As endogenous control $\beta$-actin is used. Statistical analysis was performed as described in 'Subjects and methods' section. ${ }^{*} P<0.05$.

NIS gene. This difference, which is particularly evident in the results of our FTC-133 cell assays, adds further support to the hypothesis that these two thyroid-specific genes are subjected to different forms of epigenetic control in thyroid cancers.

\section{Effects of MEK-Akt inhibitors on thyroid cell proliferation}

The MTT assay was used to evaluate the effects of U0126 and B2311 (24 and $48 \mathrm{~h}$ of exposure) on FTC-133 and BCPAP cell viability. As shown in Fig. 5, each of the inhibitors significantly reduced the viability of FTC-133 cells (reductions vs controls of $\sim 20 \%$ with U0126 and $30 \%$ with B2311, after $48 \mathrm{~h}$ of exposure). In BCPAP cells, both inhibitors also reduced viability, but the effects were already highly significant $(P<0.001)$ after $24 \mathrm{~h}$ of exposure (reductions of 30\% with U0126 and 20\% with B2311), and the reductions observed at $48 \mathrm{~h}$ were larger than those seen in FTC-133 cells (e.g. 35\% with U1026 and 45\% with B2311) (Fig. 5).

\section{Discussion}

Differential alteration of NIS and TSHR expression in thyroid cancer has been frequently reported. Using an in vivo model of normal human thyroid cells, we previously demonstrated that TSH suppression affects NIS mRNA levels but not those of TSHR (Bruno et al. 2005). Characterization of the elements that regulate TSHR (Kakinuma et al. 1996) and NIS (Chiefari et al. 2002) expression has stimulated/facilitated attempts to identify the roles these genes play in human thyroid cancer. Most studies have found that NIS expression in thyroid cancers is reduced or absent (except for some cases with defective membrane transport) (Kogai \& Brent 2012), whereas TSHR expression in these tumors is often preserved (Brabant et al. 1991, Ohta et al. 1991, Lazar et al. 1999, Sheils \& Sweenwy 1999, Tanaka et al. 2000, Durante et al. 2007; Sponziello, Durante C, Russo D \& Filetti S, 2013, unpublished observations). The latter property of most thyroid cancers, combined with the TSH stimulation of NIS expression and function, has been and is currently exploited for the TSH-induced radioiodine conventional treatment of differentiated thyroid malignancies (Schlumberger et al. 2007, Wartofsky \& Van Nostrand 2012).

In this study, striking differences were noted between the NIS/TSHR expression patterns observed in the various thyroid cancer cell lines we investigated, under basal conditions and after suppression of tumorigenic signaling pathways. Responses to MEK and Akt inhibitors were influenced in part by the genotypic alterations found in these cell lines. In BCPAP cells, for example, which are characterized by activating BRAF mutation (Schweppe et al. 2008), inhibition of ERK phosphorylation with U0126 upregulated the expression of NIS and TSHR. Phosphorylation of ERK has been implicated as a major mechanism underlying the BRAF-dependent loss of differentiation reported in many studies (Knauf \& Fagin 2009), and our findings are thus consistent with the proposed use of inhibitors like U0126 to treat thyroid cancer (Puxeddu et al. 2011). The TSHR and NIS expression patterns were quite different in FTC-133 cells, which

Published by Bioscientifica Ltd. 

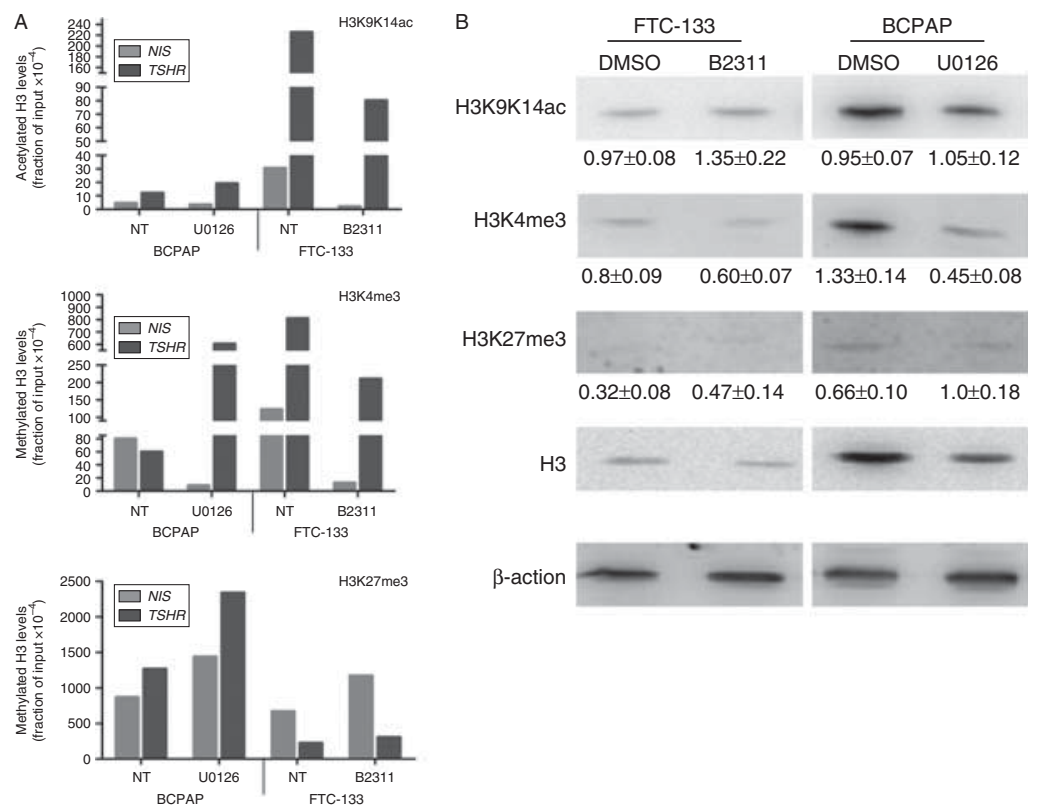

\section{Figure 4}

Effects on histone $\mathrm{H} 3$ post-translational modifications of TSHR and NIS genes in BCPAP and FTC-133. (A) ChIP assays. BCPAP cells were treated with U0126 and FTC-133 with B2311 for $24 \mathrm{~h}$. Bars indicate levels of acetylation at lysines 9 and 14 (top), trimethylation at lysine 4 (middle), and trimethylation at lysine 27 (bottom). NT, not treated. Each bar represents the mean value of three different determinations. For each bar S.D. is not above $15 \%$ of each value. (B) Basal histones levels. Western blots were performed as described in 'Subjects and methods' section. DMSO indicates

harbor a defective PTEN gene that causes activation of the Akt-dependent pathway (Liu et al. 2011). In this study, B2311-mediated inhibition of Akt phosphorylation upregulated the expression of NIS, but it markedly downregulated that of the TSHR gene, which suggests that expression of the latter gene - at least in this cell line - may be associated with the activation of growthpromoting signals. The findings regarding the TSHR are limited to only one cell line investigated, FTC-133, and could not be reproduced in other cell lines, because most of them show loss of TSHR expression (Pilli et al. 2009; Sponziello M, Durante C, Russo D \& Filetti S, 2013, unpublished observations), probably as a result of the cells' adaptation to in vitro growth conditions (Van Staveren et al. 2007). However, the NIS/TSHR expression pattern of FTC-133 resembles that observed in thyroid cancer cells in vivo, where TSHR expression is often preserved or only mildly decreased. Extension of our investigation to other thyroid-specific genes demonstrated a heterogeneous pattern of gene expression, supporting the concept of gene- and cell line-specific behavior, due to the different origin of the thyroid cancer cell lines. cell treated by vehicle alone. Numbers below images of H3K9K14ac, $\mathrm{H} 3 \mathrm{~K} 4 \mathrm{me} 3$, and $\mathrm{H} 3 \mathrm{~K} 27 \mathrm{me} 3$ indicate mean values \pm s.D. of triplicate evaluation. In order to evaluate levels of post-translational modifications, each number has been obtained by normalization first with $\beta$-actin and then with total $\mathrm{H} 3$ histone levels (H3). All differences except those between DMSO and U0126 in BCPAP cells are statistically not significant. For each antibody an immunoblot representative of three experiments is shown.

Our hypothesis that the expression of NIS and TSHR is differentially regulated is also supported by our epigenetic data, especially the results of experiments conducted with FTC-133 cells. In this cell line, under basal conditions and after treatment with the Akt inhibitor, the correlation between TSHR mRNA levels and post-translation modifications of histone $\mathrm{H} 3$ was in accordance with current knowledge on the effects on gene expression of specific histone modifications (Füllgrabe et al. 2011). FTC-133 cells exhibited increased levels of H3K27me3 (which indicates transcriptional silencing) and reduced levels of H3K9K14ac and H3K4me3 (which are transcription-activating marks). In contrast, this is not true for expression of the NIS gene (decrease in H3K9K14ac and H3K4me3 levels and increase in H3K27me3 after treatment with the Akt inhibitor). In addition, even in BCPAP cells, $\mathrm{H} 3$ histone posttranslational modifications resulted partially coherent with the current models of how these epigenetic marks control transcription only in the case of TSHR. However, our epigenetic data regarding both TSHR and NIS indicate that each cell line possesses its own profile, highlighting the extreme variability of this phenotype.

Published by Bioscientifica Ltd. 

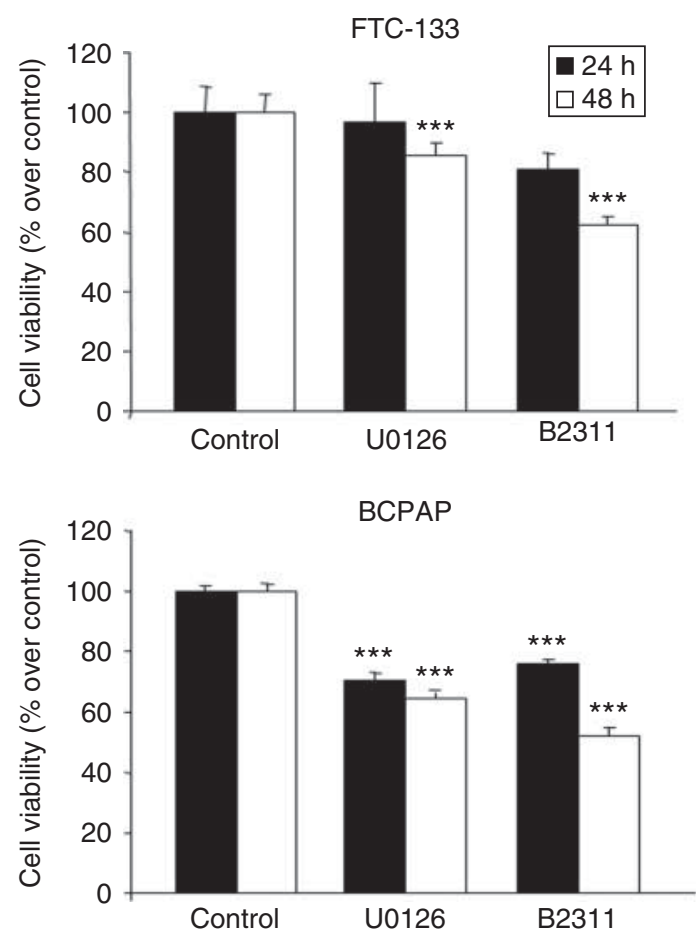

Figure 5

Effects of MEK and Akt inhibitors on FTC-133 and BCPAP cell viability. BCPAP and FTC-133 were treated for 24 and $48 \mathrm{~h}$ with $\mathrm{U} 0126(10 \mu \mathrm{M})$ or B2311 $(0.5 \mu \mathrm{M})$, and MTT assays were performed as described in 'Subjects and methods' section. Bars indicate the percentage of viable cells vs controls (untreated cells) and represent means \pm s.D. of three experiments. $* * * P<0.001$.

Thus, a major finding of our study is that in thyroid cancer cells MEK and Akt signaling pathways control posttranslational modifications of histones at specific genes. Regulation of these epigenetic marks by signaling pathways important in cancer is an emerging notion. Studies conducted in neural stem cells, for example, have shown that MEK pathway activation modifies the effects of retinoic acid on H3K4me3 levels of various genes (Ekici et al. 2008), and the activation of the Akt pathway in MCF-7 breast cancer cells reduces the levels of H3K27me3 through phosphorylation of EZH2 (Bredfeldt et al. 2010).

Thus far, the correlation between tumor aggressiveness and histone modifications has been investigated exclusively at the overall only for global (and not genespecific) histone modifications (Puppin et al. 2011). Our data clearly indicate that signaling through the MEK and Akt pathways in thyroid cancer cells exerts a contemporary control on distinct post-translational histone modifications, so that their ultimate effects are gene-specific. It is also important to recall that suppression of the MAPK and PI3K/Akt pathways and inhibition of histone deacetylase activity have all been shown to induce NIS expression and radioiodine uptake even in certain non-thyroid human cancer cells (Liu \& Xing 2012). Finally, in our cell lines, such modifications appear when the expected effects on the cell growth are still limited to an $\sim 30 \%$ inhibition of proliferation rate.

As epigenetic marks play major roles in the control of gene expression, further studies are needed to understand how Akt and MEK, as well as other signaling pathways, regulate gene-specific histone post-translational modifications may provide new hints for a better knowledge of mechanisms underlying thyroid tumorigenesis.

Declaration of interest

The authors declare that there is no conflict of interest that could be perceived as prejudicing the impartiality of the research reported.

\section{Funding}

This work was supported by Fondazione 'Umberto Di Mario' ONLUS, Banca d'Italia, Ministero dell'Istruzione, Università e Ricerca Scientifica (MIUR-PRIN 2009) and Associazione Italiana Ricerca Cancro (AIRC), grant number IG 10296.

\section{Acknowledgements}

The authors thank Marian E Kent for the language revision of the manuscript.

\section{References}

Arturi F, Russo D, Giuffrida D, Schlumberger M \& Filetti S 2000 Sodiumiodide symporter (NIS) gene expression in lymph-node metastases of papillary thyroid carcinomas. European Journal of Endocrinology 143 623-627. (doi:10.1530/eje.0.1430623)

Arturi F, Russo D, Bidart JM, Scarpelli D, Schlumberger M \& Filetti S 2001 Expression pattern of the pendrin and sodium/iodide symporter (NIS) gene in human thyroid carcinoma cell lines and human thyroid tumors. European Journal of Endocrinology 145 129-135. (doi:10.1530/ eje.0.1450129)

Barsky SH, Sternlicht MD, Safarians S, Nguyen M, Chin K, Stewart SD, Hiti AL \& Gray JW 1997 Evidence of a dominant transcriptional pathway which regulates an undifferentiated and complete metastatic phenotype. Oncogene 15 2077-2091. (doi:10.1038/sj.onc.1201379)

Brabant G, Maenhaut C, Kohrle J, Scheumann G, Dralle H, Hoang-Vu C, Hesch RD, von zur Mühlen A, Vassart G \& Dumont JE 1991 Human thyrotropin receptor gene: expression in thyroid tumors and correlation to markers of thyroid differentiation and dedifferentiation. Molecular and Cellular Endocrinology 82 R7-R12. (doi:10.1016/ 0303-7207(91)90018-N)

Braunstein M, Sobel RE, Allis CD, Turner BM \& Broach JR 1996 Efficient transcriptional silencing in Saccharomyces cerevisiae requires a heterochromatin histone acetylation pattern. Molecular and Cellular Biology 16 4349-4356.

Bredfeldt TG, Greathouse KL, Safe SH, Hung MC, Bedford MT \& Walker CL 2010 Xenoestrogen-induced regulation of EZH2 and histone 
methylation via estrogen receptor signaling to PI3K/AKT. Molecular Endocrinology 24 993-1006. (doi:10.1210/me.2009-0438)

Bruno R, Ferretti E, Tosi E, Arturi F, Giannasio P, Mattei T, Scipioni A, Presta I, Morisi R, Gulino A et al. 2005 Modulation of thyroid-specific gene expression in normal and nodular human thyroid tissues from adults: an in vivo effect of thyrotropin. Journal of Clinical Endocrinology and Metabolism 90 5692-5697. (doi:10.1210/jc.2005-0800)

Celano M, Sponziello M, Tallini G, Maggisano V, Bruno R, Dima M, Di Oto E, Redler A, Durante C, Sacco R et al. 2013 Increased expression of pro-angiogenic factors and vascularization in thyroid hyperfunctioning adenomas with and without TSH receptor activating mutations. Endocrine 43 147-153. (doi:10.1007/s12020-012-9747-3)

Chiefari E, Brunetti A, Arturi F, Bidart JM, Russo D, Schlumberger M \& Filetti S 2002 Increased expression of AP2 and Sp1 transcription factors in human thyroid tumors: a role in NIS expression regulation? BMC Cancer 2 35. (doi:10.1186/1471-2407-2-35)

D’Agostino M, Voce P, Celano M, Sponziello M, Moretti S, Maggisano V, Verrienti A, Durante C, Filetti S, Puxeddu E et al. 2012 Sunitinib exerts only limited effects on the proliferation and differentiation of anaplastic thyroid cancer cells. Thyroid 22 138-144. (doi:10.1089/thy.2011.0060)

Durante C, Puxeddu E, Ferretti E, Morisi R, Moretti S, Bruno R, Barbi F, Avenia N, Scipioni A, Verrienti A et al. 2007 B-RAF mutations in papillary thyroid carcinomas inhibit genes involved in iodine metabolism. Journal of Clinical Endocrinology and Metabolism 92 2840-2843. (doi:10.1210/jc.2006-2707)

Ekici M, Hohl M, Schuit F, Martínez-Serrano A \& Thiel G 2008 Transcription of genes encoding synaptic vesicle proteins in human neural stem cells: chromatin accessibility, histone methylation pattern, and the essential role of rest. Journal of Biological Chemistry $\mathbf{2 8 3}$ 9257-9268. (doi:10.1074/jbc.M709388200)

Füllgrabe J, Kavanagh E \& Joseph B 2011 Histone onco-modifications. Oncogene 30 3391-3403. (doi:10.1038/onc.2011.121)

Galrão AL, Sodré AK, Camargo RY, Friguglietti CU, Kulcsar MA, Lima EU, Medeiros-Neto G \& Rubio IG 2013 Methylation levels of sodium-iodide symporter (NIS) promoter in benign and malignant thyroid tumors with reduced NIS expression. Endocrine 43 225-229. (doi:10.1007/ s12020-012-9779-8)

Gérard AC, Daumerie C, Mestdagh C, Gohy S, De Burbure C, Costagliola S, Miot F, Nollevaux MC, Denef JF, Rahier J et al. 2003 Correlation between the loss of thyroglobulin iodination and the expression of thyroid-specific proteins involved in iodine metabolism in thyroid carcinomas. Journal of Clinical Endocrinology and Metabolism $\mathbf{8 8}$ 4977-4983. (doi:10.1210/jc.2003-030586)

Hou P, Liu D, Ji M, Liu Z, Engles JM, Wahl RL \& Xing M 2009 Induction of thyroid gene expression and radioiodine uptake in melanoma cells: novel therapeutic implications. PLOS ONE 4 1-11. (doi:10.1371/journal. pone.0005361)

Hou P, Bojdani E \& Xing M 2010 Induction of thyroid gene expression and radioiodine uptake in thyroid cancer cells by targeting major signaling pathways. Journal of Clinical Endocrinology and Metabolism 95 820-828. (doi:10.1210/jc.2009-1888)

Ieda M, Fu JD, Delgado-Olguin P, Vedantham V, Hayashi Y, Bruneau BG \& Srivastava D 2010 Direct reprogramming of fibroblasts into functional cardiomyocytes by defined factors. Cell 142 375-386. (doi:10.1016/ j.cell.2010.07.002)

Kakinuma A, Chazenbalk G, Filetti S, McLachlan SM \& Rapoport B 1996 Both the $5^{\prime}$ and $3^{\prime}$ noncoding regions of the thyrotropin receptor messenger ribonucleic acid influence the level of receptor protein expression in transfected mammalian cells. Endocrinology 137 2664-2669. (doi:10.1210/en.137.7.2664)

Knauf JA \& Fagin JA 2009 Role of MAPK pathway oncoproteins in thyroid cancer pathogenesis and as drug targets. Current Opinion in Cell Biology 21 296-303. (doi:10.1016/j.ceb.2009.01.013)

Kogai T \& Brent GA 2012 The sodium iodide symporter (NIS): regulation and approaches to targeting for cancer therapeutics. Pharmacology \& Therapeutics 135 355-370. (doi:10.1016/j.pharmthera.2012.06.007)
Kogai T, Sajid-Crockett S, Newmarch LS, Liu YY \& Brent GA 2008 Phosphoinositide-3-kinase inhibition induces sodium/iodide symporter expression in rat thyroid cells and human papillary thyroid cancer cells. Journal of Endocrinology 199 243-252 (Erratum in: Journal of Endocrinology 2008199 (3) 500). (doi:10.1677/JOE-08-0333)

Lavarone E, Puppin C, Passon N, Filetti S, Russo D \& Damante G 2013 The PARP inhibitor PJ34 modifies proliferation, NIS expression and epigenetic marks in thyroid cancer cell lines. Molecular and Cellular Endocrinology 365 1-10. (doi:10.1016/j.mce.2012.08.019)

Lazar V, Bidart JM, Caillou B, Mahé C, Lacroix L, Filetti S \& Schlumberger M 1999 Expression of the $\mathrm{Na}^{+} / \mathrm{I}^{-}$symporter gene in human thyroid tumors: a comparison study with other thyroid-specific genes. Journal of Clinical Endocrinology and Metabolism 84 3228-3234. (doi:10.1210/ jc.84.9.3228)

Liu Z \& Xing M 2012 Induction of sodium/iodide symporter (NIS) expression and radioiodine uptake in non-thyroid cancer cells. PLoS ONE 7 e31729. (doi:10.1371/journal.pone.0031729)

Liu R, Liu D, Trink E, Bojdani E, Ning G \& Xing M 2011 The Akt-specific inhibitor MK2206 selectively inhibits thyroid cancer cells harboring mutations that can activate the PI3K/Akt pathway. Journal of Clinical Endocrinology and Metabolism 96 E577-E585. (doi:10.1210/ jc.2010-2644)

Liu YY, Zhang X, Ringel MD \& Jhiang SM 2012 Modulation of sodium iodide symporter expression and function by LY294002, Akti-1/2 and rapamycin in thyroid cells. Endocrine-Related Cancer 19 291-304. (doi:10.1530/ERC-11-0288)

Livak KJ \& Schmittgen TD 2001 Analysis of relative gene expression data using real-time quantitative PCR and the 2(-Delta Delta $C(\mathrm{~T})$ ). Methods 25 402-408. (doi:10.1006/meth.2001.1262)

Ohta K, Endo T \& Onaya T 1991 The mRNA levels of thyrotropin receptor, thyroglobulin and thyroid peroxidase in neoplastic human thyroid tissues. Biochemical and Biophysical Research Communications 174 1148-1153. (doi:10.1016/0006-291X(91)91540-S)

Pilli T, Prasad KV, Jayarama S, Pacini F \& Prabhakar BS 2009 Potential utility and limitations of thyroid cancer cell lines as models for studying thyroid cancer. Thyroid 19 1333-1342. (doi:10.1089/thy.2009.0195)

Pokholok DK, Harbison CT, Levine S, Cole M, Hannett NM, Lee TI, Bell GW, Walker K, Rolfe PA, Herbolsheimer E et al. 2005 Genome-wide map of nucleosome acetylation and methylation in yeast. Cell 122 517-527. (doi:10.1016/j.cell.2005.06.026)

Puppin C, D'Aurizio F, D'Elia AV, Cesaratto L, Tell G, Russo D, Filetti S, Ferretti E, Tosi E, Mattei T et al. 2005 Effects of histone acetylation on sodium iodide symporter promoter and expression of thyroid-specific transcription factors. Endocrinology 146 3967-3974. (doi:10.1210/ en.2005-0128)

Puppin C, Passon N, Lavarone E, Di Loreto C, Frasca F, Vella V, Vigneri R \& Damante G 2011 Levels of histone acetylation in thyroid tumors. Biochemical and Biophysical Research Communications 411 679-683. (doi:10.1016/j.bbrc.2011.06.182)

Puxeddu E, Durante C, Avenia N, Filetti S \& Russo D 2008 Clinical implication of BRAF mutation in thyroid carcinoma. Trends in Endocrinology and Metabolism 19 138-145. (doi:10.1016/j.tem. 2007.12.003)

Puxeddu E, Romagnoli S \& Dottorini ME 2011 Targeted therapies for advanced thyroid cancer. Current Opinion in Oncology 23 13-21. (doi:10.1097/CCO.0b013e328340cf94)

Rando OJ 2007 Global patterns of histone modifications. Current Opinion in Genetics \& Development 17 94-99. (doi:10.1016/j.gde.2007.02.006)

Russo D, Damante G, Puxeddu E, Durante C \& Filetti S 2011 Epigenetics of thyroid cancer and novel therapeutic targets. Journal of Molecular Endocrinology 46 R73-R81. (doi:10.1530/JME-10-0150)

Russo D, Durante C, Bulotta S, Puppin C, Puxeddu E, Filetti S \& Damante G 2013 Targeting histone deacetylase in thyroid cancer. Expert Opinion on Therapeutic Targets 17 179-193. (doi:10.1517/14728222.2013. 740013) 
Santos-Rosa H, Schneider R, Bannister AJ, Sherriff J, Bernstein BE, Emre NC, Schreiber SL, Mellor J \& Kouzarides T 2002 Active genes are trimethylated at K4 of histone H3. Nature 419 407-411. (doi:10.1038/ nature01080)

Schlumberger M, Lacroix L, Russo D, Filetti S \& Bidart JM 2007 Defects in iodide metabolism in thyroid cancer and implications for the follow-up and treatment of patients. Nature Clinical Practice. Endocrinology \& Metabolism 3 260-269. (doi:10.1038/ncpendmet0449)

Schweppe RE, Klopper JP, Korch C, Puqazhenthi U, Benezra M, Knauf JA, Fagin JA, Marlow LA, Copland JA, Smallridge RC et al. 2008 Deoxyribonucleic acid profiling analysis of 40 human thyroid cancer cell lines reveals cross-contamination resulting in cell line redundancy and misidentification. Journal of Clinical Endocrinology and Metabolism 93 4331-4341. (doi:10.1210/jc.2008-1102)

Sheils OM \& Sweenwy EC 1999 TSH receptor status of thyroid neoplasms TaqMan RT-PCR analysis of archival material. Journal of Pathology 188 87-92. (doi:10.1002/(SICI)1096-9896(199905)188:1<87::AIDPATH322>3.0.CO;2-5)

Tanaka K, Otsuki T, Sonoo H, Yamamoto Y, Udagawa K, Kunisue H, Arime I, Yamamoto S, Kurebayashi J \& Shimozuma K 2000 Semi-quantitative comparison of the differentiation markers and sodium iodide symporter messenger ribonucleic acids in papillary thyroid carcinomas using RT-PCR. European Journal of Endocrinology 142 340-346. (doi:10.1530/eje.0.1420340)

Trapasso F, Iuliano R, Chiefari E, Arturi F, Stella A, Filetti S, Fusco A \& Russo D 1999 Iodide symporter gene expression in normal and transformed rat thyroid cells. European Journal of Endocrinology 140 447-451. (doi:10.1530/eje.0.1400447)

Van Staveren WC, Solís DW, Delys L, Duprez L, Andry G, Franc B, Thomas G, Libert F, Dumont JE, Detours V et al. 2007 Human thyroid tumor cell lines derived from different tumor types present a common dedifferentiated phenotype. Cancer Research 67 8113-8120. (doi:10.1158/0008-5472.CAN-06-4026)

Wartofsky L \& Van Nostrand D 2012 Radioiodine treatment of welldifferentiated thyroid cancer. Endocrine 42 506-513. (doi:10.1007/ s12020-012-9729-5)

Xing M 2010 Genetic alterations in the phosphatidylinositol-3 kinase/Akt pathway in thyroid cancer. Thyroid 20 697-705. (doi:10.1089/ thy.2010.1646)

Xing M, Usadel H, Cohen Y, Tokumaru Y, Guo Z, Westra WB, Tong BC, Tallini G, Udelsman R, Califano JA et al. 2003 Methylation of the thyroid-stimulating hormone receptor gene in epithelial thyroid tumors: a marker of malignancy and a cause of gene silencing. Cancer Research 63 2316-2321.

Received in final form 4 December 2013

Accepted 10 December 2013

Accepted Preprint published online 18 December 2013
(C) 2014 Society for Endocrinology Printed in Great Britain
Published by Bioscientifica Ltd. 